\title{
Dairi Traditional Food Inventory In The Design Of Culinary Branding In Dairi
}

\author{
Tina Taviani \\ Medan Tourism Polytechnic \\ Medan, Indonesia \\ tinatavianinasution@yahoo.com
}

\begin{abstract}
This study has three research objectives,(1) Prepare a detailed inventory of traditional Dairi foods which include: (a) Types of traditional foods (b) Traditional food processing methods, (c) Economic aspects and (d) Documentation, Objectives (2) Developing traditional food development alternatives and (3) designing Branding on traditional food in Dairi District.The type of this research is survey research with descriptive method. The results Based on a survey conducted in Sidikalang City identified a number of 5 types of traditional food. The main ingredients most widely used for making traditional food are Rice (80\%), then other ingredients (20\%). Dairi traditional foods, based on the way of processing can be categorized into four, namely: (1) steamed, (2) fried, (3) burned, and (4) boiled. Based on interviews with resource persons and traditional food community figures in Dairi, several alternative development that can be done are: Identification and Inventory of traditional food, Preparing the profile of traditional food in the area as food information and counseling and Promotion, Encouraging the development of traditional food centers with relevant agencies, private and community; Provision of soft loans for additional capital.
\end{abstract}

Keywords: Inventory, Traditional food

\section{PRELIMINARY}

\section{Background}

Nusantara food is a collection of various foods that characterize each region with different cooking techniques according to the area concerned.

Nusantara food is food consumed by certain ethnic groups, with specific areas and processed from nyang recipes known to the local community, the ingredients are obtained from local sources, and in accordance with the tastes of the surrounding community.

The concept of archipelago food is traditional food in an area that is very bound to local culture and has its own distinctive characteristics in each region. Archipelago food is often referred to as traditional food which is a form of regional culture that is regional, specific, has a variety of types and types that reflect the natural potential of each region.
Traditional food is not only just to characterize an area, but more than that food at this time can also be sold and promoted to support tourism which can further support the income of an area.

Related to traditional food, Indonesian people have always had a culture of traditional food since time immemorial. Various regions in Indonesia have a variety of cuisines, traditional snacks and drinks that enable Indonesian people to choose and consume foods that are delicious, healthy and safe, in accordance with the cultural morals and beliefs of the people.

Dairi Regency is one of the districts around the priority development area of Lake Toba, until now there are still many improvements in facilities and infrastructure needed to support the Lake Toba region that is convenient for tourists to visit. Tourists will feel comfortable in a tourist attraction if there are supporting facilities such as hotels and food to be enjoyed. Dairi Regency has the potential of traditional food which is diverse but not wellstocked. Therefore, this study will attempt to inventory traditional foods in Dairi Regency. This inventory is the first step to knowing the potential of traditional Dairi foods. Inventories are carried out in detail to the materials and methods of manufacture with the aim that alternative development can be sought so that it is economically efficient in increasing income. The results of the inventory are also expected to be a data base on traditional food in Dairi Regency which later can be made as a traditional culinary branding in Dairi Regency.

\section{Formulation of the problem}

As for the formulation of the problem in this study are:

1. What is a detailed inventory of traditional foods in Dairi Regency which includes types of food, processing methods, economic aspects and documentation?

2. What strategies can be used in developing traditional food in Dairi Regency?

3. What has been done by the Dairi Regency Government? 


\section{Research purposes}

The objectives of this research are:

1. Compile a detailed inventory of traditional foods in Dairi District which includes types of traditional food, processing methods, economic aspects and food documentation.

2. Determine a good development strategy so that traditional foods can be developed economically.

3. Knowing how far the promotion has been done by the local government.

\section{Benefits of research}

1. Detailed inventory results on traditional food in Dairi District can be used as a means to identify potential Dairi traditional foods.

2. The results of developing the development strategy are expected to improve the economy of the community in Dairi Regency.

3. Can formulate more effective promotions to introduce traditional food in Dairi Regency.

\section{CONCEPTUAL FRAMEWORK}

\section{Indonesian food}

Indonesian cuisine is a reflection of diverse cultures and traditions originating from the archipelago which consists of about 6,000 islands and holds an important place in Indonesia's national culture in general and almost all Indonesian cuisine is rich in herbs derived from spices such as candlenut, chili, temu Kunci, galuas , ginger, kencur, turmeric, coconut and palm sugar followed by the use of cooking techniques according to materials and traditions that also have influence through trade originating from India, China, the Middle East and Europe.

Basically there is no single form of "Indonesian cuisine", but rather, the diversity of regional cuisine that is influenced locally by Indonesian culture and foreign influences. For example, rice that is processed into white rice, ketupat or lontong (steamed rice) is the staple food for the majority of the Indonesian population but for the eastern part it is more commonly used as well as corn, sago, cassava and sweet potatoes. The form of landscape presentation is generally presented in most Indonesian foods in the form of staple foods with side dishes in the form of meat, fish or vegetables on the side of the plate.

Throughout its history, Indonesia has been involved in world trade thanks to its location and natural resources. Indonesian native cooking techniques and food ingredients developed and were later influenced by the culinary arts of India, the Middle East, China, and finally Europe. Spanish and Portuguese traders brought various foodstuffs from the Americas long before the Dutch succeeded in conquering Indonesia. Maluku Island which is famous as the "Spice Islands", also donates native Indonesian spices to the world of culinary arts. Culinary arts in the eastern part of Indonesia are similar to Polynesian and Melanesian cooking arts.

Sumatran cuisine, for example, often displays Middle Eastern and Indian influences, such as the use of curry spices in meat and vegetable dishes, while Javanese cuisine develops from native Indonesian cooking techniques. Chinese cultural elements can be observed in several Indonesian dishes.

From its definition, traditional food is food and drink, including snacks and mixed ingredients which are traditionally used and have long developed specifically in the Indonesian region or society. Usually traditional foods are prepared from recipes that are already known to the local community with ingredients obtained from local sources that have flavors that are relatively in accordance with the tastes of the local community (http://www.deptan.go.id).

Kuhnlein and Receveur (Kwik, 2008) defines traditional food as an implication of a social cultural process. "Traditional food systems of indigenous peoples can be defined to items that are from the local, natural environment that is culturally acceptable. It also includes the sociocultural meanings, acquisition / processing techniques, use, composition, and nutritional consequences for the people using the food "(Kuhnlein and Receveur 1996: 417).

From this understanding, traditional food does not only function as a staple food consumed only, but also has a function as a symbol of the identity of a particular society.

Traditional food is food that is consumed by the ethnic group and specific region, processed from recipes known to the community, the ingredients are obtained from local sources and have a taste that is relatively in accordance with the tastes of the local community. Local Food, is food produced locally (one region / region) for economic and or consumption purposes. Local food is in the form of food both primary and secondary commodities. Original food, is a food whose origin is biologically found in an area (http://www.deptan.go.id).

\section{Nusantara Traditional Seasoning}

Various Spices in Traditional Archipelago Foods

The presence of herbs in cooking is very important. Taste of food is formed, one of which is the addition of herbs. Of the many types of spices, leaf spices such as bay leaves, orange leaves and pandanus include spices that are often added to cooking. 
Herbs or herbs are aromatic plants which are added to food ingredients to arouse taste and flavor. Spices are herbs that have gone through a drying process, so that spices can last long and last, spices are also known as dried herbs.

\section{Main Source of Bumbu Nusantara}

- Fresh Seasonings

Is the seasoning obtained from the plant directly. Used without needing to be dried first. Although the name is fresh seasoning, it does not have to be used as soon as it is harvested, because fresh herbs generally do not last long.

Example:

1. Chili: Red curly chili, cayenne, big red chili, green chili

2. Tamarind, tamarind

3. Kencur

4. Turmeric

5. Ginger

6. Galangal

7. Lock

Seasoning function is:

- Giving Taste and Aroma

- Spicy flavor

- Taste with a specific scent

Scented leaves also contribute much to the delicacy of traditional Indonesian cuisine. Examples: spring onions, curry leaves, turmeric leaves, orange leaves, lemongrass, pandan leaves, basil, bay leaves, wavy, mangkokan leaves.

\section{- Dry Spices}

Is the origin of fresh herbs which are then dried for drying. The purpose of drying can be to make it durable or to remove the aroma. Some of our herbs do not smell when it's fresh. Example: Nutmeg, fennel, aniseed, dried fruit acid, suntilic acid, kandis acid, ebi, cumin, dried chili, cloves, candlenut, cardamom, cinnamon, coriander, pepper.

\section{- Artificial Spices}

That is the ingredients we make ourselves or mix ourselves. Examples: sweet soy sauce, petis, tauco, tempoyak, papaya and shrimp paste.

- Instant seasoning

This seasoning is usually made specifically for each type of cuisine. The processor only adds the main ingredients of the complementary ingredients and the steps follow, as shown on the packaging. Generally, it is processed in the form of a paste that has been preserved by sautéing and oiling. Sold in sachet packaging.

Some examples include: lodeh vegetable seasoning, rendang seasoning, woku seasoning, Betawi soto seasoning, opor seasoning, fried chili seasoning, balado seasoning, stew seasoning, gule seasoning, palm curry seasoning, and others.

\section{The base of the archipelago}

A mixture of several spices and herbs that have been mashed and ready to be used to help facilitate processing because it is half-finished.

\section{Basic spice classification}

1. Red base seasoning

Spices that are often used to produce red in cooking. Red spices are: red onion, garlic and tomatoes. Usually used for fried rice or chili sauce.

2. White base seasoning

Seasonings with the main ingredients are: shallots, garlic, candlenut, lemongrass, ginger, galangal, and coriander. This spice is often used as an ingredient that is essentially white in color for example: soto, opor, lodeh, and tamarind vegetables

3. Yellow base seasoning

Seasonings with basic ingredients include: shallots, garlic, candlenut, turmeric, lemongrass, ginger, galangal and coriander. This spice is often used in dishes such as: curry and curry.

\section{Aromatic leaf types}

In addition to herbs and spices there are also other types that are commonly added to foods, namely aromatic leaves. This aromatic leaf serves to give aroma to the processed product. Here are some leaves that are commonly used for cooking:

1. Leaves Greetings \& Greetings Koja Includes many spices used in Indonesian cuisine. The fragrant and distinctive aroma adds delicacy to curry, curry, stir and vegetable dishes. Usually used in dry or fresh form. Choose leaves that are not too young or old so that the aroma is maximal. Like bay leaves, greetings koja / curry leaves also serve to smell good, provide savory flavors and reduce fishy smell in processed meat, chicken or fish. Sumatran culinary uses the most spices that are sold in fresh and dry form.

2. Leaves of Sumatra, Malaysia and Singapore Culinary Kettle are very familiar with kesum leaves. Its savory and distinctive aroma is suitable for adding to meat, chicken or fish dishes. This leaf is usually used in fresh form. How to use it, add 3-5 leaves of kesum in each dish.

3. Cumin Leaves Its thick and downy appearance makes people call it thick leaves. This leaf is widely used in the kitchen of Sulawesi. The aroma is a combination of cumin and fennel. Slice finely and add to the soup dish to get a distinctive taste and thick texture. 
4. Suji Leaves \& Pandan Leaves Both of these leaves are usually used together. Pandan to make a variety of cakes, pudding, ice and dishes, while suji leaves give a natural green color to cakes and drinks. The use of suji leaves is usually finely ground and the water is squeezed while the pandan leaves are cut or torn.

5. Bangun-Bangun leaves This spice is widely used in Sumatran kitchens, especially the Batak area. At first glance it looks like cumin leaves but is thinner and hairy. The part used is the shoot of the young leaves. The benefits can be able to eliminate the fishy aroma in processed chicken / fish.

6. Leaf Gedi Manado people use gedi leaves to thicken, scent and give a savory flavor to the cuisine. Manado Porridge is one of the dishes that characterizes cash using gedi leaves. Use 2-4 young gedi leaves on dishes for maximum taste.

7. Leaf Miana The color is deep red, because of the beauty of the Daunya, people plant it as an ornamental plant. Miana is widely used in the Toraja kitchen. Choose the young leaves and add to processed buffalo or pork meat to reduce the sharp odor of the meat.

8. Mangkokan Leaf This leaf is also popularly known as Tapak Liman. For seasoning, use young leaves and discard the leaves before adding them to the dish. If you process the brains of beef or fish head curry, add these leaves to taste more delicious and the fishy aroma diminishes.

9. Lime Leaves Including widely used leaf spices. Soto, soup, curry, curry and kalio will be more fragrant and fresh in flavor by adding this spice. The aroma is fragrant, fresh and distinctive so it can reduce the fishy aroma of meat, chicken and seafood.

10. Turmeric Leaves The aroma is similar to turmeric, fragrant and distinctive so that it can reduce fishy aroma in meat or fish dishes. This spice is widely used in Sumatran kitchens, usually added to coconut milk dishes such as curry, curry and kalio. Choose leaves that are not too old or young so that the aroma is maximal.

11. Werot Leaves One variety of croton plants. People plant it as an ornamental plant, but Menado culinary uses it as a cooking spice. Dishes of pork, beef, buffalo and chicken will reduce their rancid smell by adding this leaf. Use young leaves, remove the dau bone and finely slice it before adding it to the dish.

\section{Various acids}

There are so many types of acids used in Indonesian cuisine. As in the kitchen Sumatra is often used Asam Gelugur. This acid is obtained from a kind of tangerine which is thinly sliced and then dried in the sun to dry. The use of this spice gives the taste and aroma of the food without making the dish cloudy. Another Javanese kitchen, the Javanese people are more familiar with Javanese acid, both fresh and already broiled. How to use it by melting it first, from the steeping water is then added to the dish to get a fresh sour taste. If you have trouble finding tamarind, Kandis acid and Sunti acid can be used instead. Both of them have the same function, which is to give an acidic taste but of different origin. Asam sunti is obtained from starfruit, while kandis acid is dried from orange peel.

\section{Seasonings from tubers}

Ginger, turmeric, kencur, temu Kunci, temu mango, and galangal are spices that belong to this category. Ginger is widely used in cooking, the aroma is distinctive and the taste is a little spicy can arouse appetite. For soupy dishes such as curry, curry, and pindang it will be more delicious and interesting if added with turmeric. Besides turmeric can also reduce the sharp and fishy aroma of animal food ingredients. Clear vegetables like spinach feel fresher and taste better if you add a few pieces to the key. Whereas Sundanese dishes such as karedok, threatened, warehousing and anointing taste are more fresh if the spices are added in the marinade. Another laos function in cooking, this seasoning has a fresh aroma and is very suitable if added to the dish from chicken, pindang and coconut milk soup. Whereas laksa cooking will feel something that feels less if without adding mango gatherings, one of the characteristics of the marinade.

\section{Onion type seasoning}

The onion family is very diverse, but what is commonly used as a spice is garlic. onion, onion, lanang / male onion, and batak or chive onion. You are certainly very familiar with garlic and onion which serves to provide a combination of flavor and fragrant and savory aroma to the cuisine. To give a lighter flavor to the dish, you should use onions. In the kitchen Sumatra is widely used Batak or Lokio onions. This onion gives a soft taste but the aroma is sharp, very suitable for seafood and chinese food. For pickles or pickles, male onions are best suited. The shape is small grain and the taste is not too sharp, feels right as a complement to the dish. 


\section{Various oranges}

The aroma and fresh fragrance in the dish can be obtained by adding a few teaspoons of orange juice. Lemon, lemon cui / lemon china, lime, and lime include some varieties of oranges commonly used as a spice. Salad sauce and soto sauce feels more fitting by adding lime juice. For cakes like bika ambon and some types of cake, it will smell better if you add lime skin grated. The orange part used is the outer skin because the flesh contains a little water.

\section{Dry seasoning}

Dry seasoning is mostly used in fine form, but there are also some that are used in whole or granular form. Fennel, cumin, cilantro, nutmeg, pepper and diabetes are more widely used in powder form. While cinnamon, secang wood, cloves and shredded are more often used in intact form. As with wet seasonings, dry seasonings also function the same as in cuisine, which provides a particular flavor and aroma according to the needs of the recipe, in addition to reducing the fishy aroma of animal foods. Like fennel, cumin, klabet, candlenut and coriander are more widely used in meat, fish or side dishes with coconut milk or broth, for example curry, curry, opor, soto etc. Nutmeg, cloves, and cinnamon, are usually more appropriately added to sweet dishes such as various cakes, cakes, pudding and drinks. While cardamom, cumin, and fennel are more widely used in Middle Eastern cuisine, such as curry, pacri, kebab and briani rice.

\section{Traditional Food Criteria}

The criteria for traditional food for ethnic groups are as follows:

a. Processed according to food recipe or spice composition that has been known and applied for generations in the family or community system.

b. Local raw materials are available, either as a result of own farming or available in the local market system.

c. The method of processing is specific in ways that have been developed by the local community.

\section{Culinary Profile of North Sumatra}

North Sumatra or better known as the City of Medan has a very diverse cultural diversity and has a multicultural life that greatly influences the culinary culture in North Sumatra today. Batak cuisine has the character of the use of natural ingredients as well as the simplicity of processing, some Batak dishes use a lot of local ingredients as spices, such as andaliman which gives a spicy sensation and taps the tip of the tongue or kecombrang (Rias) which has a tantalizing sharp aroma and patical acid or tikala acid which is full of sensation acid.

\section{RESEARCH METHODOLOGY}

\section{Types of research}

This type of research is survey research with descriptive methods. Survey research is a research that collects data at certain times with three important objectives, namely to describe natural conditions, identify measurably, and determine the relationship of something that is alive (Sukardi, 2011: 193).

The survey method is considered the best because this research is one of them that aims to obtain and collect original data to describe the situation.

\section{Research sites}

The location of this research is Dairi Regency, precisely in Sidikalang City.

\section{Types and Data Sources}

Data Type

Qualitative data includes information about research locations.

Data source

1. Primary data sources, namely the source of data obtained directly from the research respondents including the respondent's response to the factors examined.

2. Secondary data sources, namely sources of data obtained from other sources, both those that have been processed or not, which support the research. Secondary data in this study include: regional profiles as well as documents and theories from various literature used as guidelines in this study.

\section{Research Instruments}

Departing from the type of data needed in this study, in accordance with the focus of the problem, this study uses instruments or data collection tools consisting of: (1) interview guidelines, (2) direct observation or observation guidelines, (3) questionnaires, and ( 4) documentation study guidelines.

\section{Data Collection Methods and Techniques}

The data in this study were obtained by three methods, namely:

a Literature study

Through library information to collect data relevant to the research objectives.

b. Interview

This study uses a survey with a conventional approach, namely individual interviews. This is done so that time is more flexible, researchers 
obtain additional information, and to allow for in-depth interviews (Sukardi, 2011: 200).

c. Questionnaire

\section{Data Analysis Methods and Methods}

In this study the author uses a questionnaire as an instrument for collecting data in the survey method. The type of questionnaire used by the authors in this study is an open questionnaire. Filling in the questionnaire was done by self administered questionnaires where the respondents filled out the questionnaires themselves and the respondents who were given the questionnaire were.

\section{Methods and Techniques of Presentation of Data Analysis Results}

The entire data in this study were analyzed qualitatively, the results of data analysis will be described in a narrative, factual, and actual, so that it represents the entire dimension of the research as required by the focus of the problem under study.

\section{RESULTS AND DISCUSSION}

\section{Description of Research Object}

Dairi Regency is a district in the province of North Sumatra, Indonesia. The capital is Sidikalang. Sidikalang is the name of a sub-district in Dairi district, North Sumatra. Sidikalang which is also the capital of Dairi Regency is Geographically located in the northwest of North Sumatra Province with an area of approximately $191,625 \mathrm{Ha}$ or around $2.67 \%$ of the total area of North Sumatra province $(71,680,000 \mathrm{Ha})$

Dairi Regency administratively consists of 15 sub-districts, with 145 villages. If viewed from the Topographical aspect, Sidikalang District which is located at an altitude of 1,066 m above sea level consists of mountains and hills with varying slopes. The condition of the environment that is still quite natural and the cool air and the population that is still in balance with the area, makes Sidikalang a relatively comfortable area to inhabit.

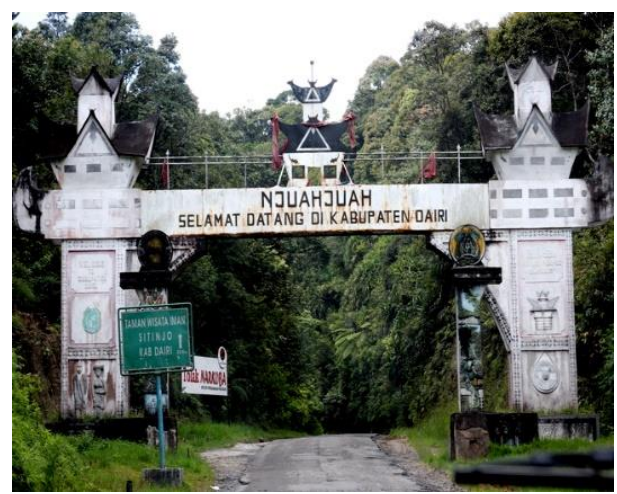

Figure 1. Sidikalang City

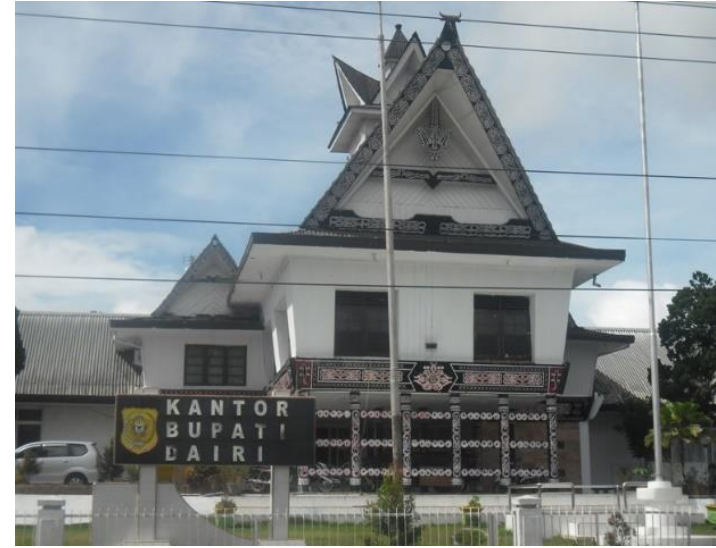

Figure 2. Mayor's Office

\section{PAKPAK SUKU}

The Pakpak tribe is widely found in North Sumatra, namely in Dairi, not because this tribe is not famous, but because this tribe is a tribe that is neglected even by its own owners. Some sources indicate that the Pakpak tribe is the oldest tribe from the Batak clan. Even though most Pakpak people don't want to be called Batak. Not because of selfishness, but rather to show that the Pakpak tribe exists and is free from the shadow of the Batak tribe which has been better known by the world.

In plain view, it is difficult to distinguish between Batak and Pakpak tribes, so scientists (who we don't know the motive) classify the Pakpak tribe into the Batak sub-tribe. But in fact there are many fundamental differences from these two tribes, ranging from traditional clothing, traditional houses, customary events, clans, languages and beliefs.

But this tribe is now threatened with extinction. Historic sites about this tribe are very rare. Traditional houses that reflect the original culture of Pakpak people are now almost gone. There are many reasons why this happened because of being ignored by the government, because many relics were damaged, destroyed and not even a few were stolen by irresponsible people.

\section{TRUST}

At present the majority of the Pakpak tribe are mostly Muslim and Christian.

\section{TRADITIONAL CLOTHES}

The daily wear of the Pakpak community in general, has been adapted to the times. However, in certain customary events, the Pakpak community uses their traditional clothing. Namely:

Man

- rub

- bro

- ucang machete 


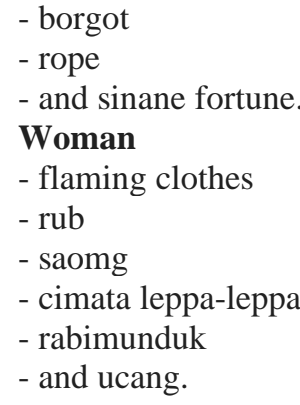

\section{General Conditions of Sidikalang City}

The majority of the Sidikalang tribe are Dairi tribes. In addition, many residents of the Toba Batak, Karo, Javanese, and other tribes. Then the religion adopted by the Sidikalang people is Christian 55.42\% (Protestant Christian $47.27 \%$ and Catholic $8.21 \%$ ) and Islam $44.58 \%$. [1] The people in Sidikalang are very maintaining tolerance in religion. The topographic state which consists of mountains and hills and very cool air is one of the determining factors for the majority of Dairi's work in general, which is now a farmer. Some of the leading agricultural commodities from Kab. Dairi includes Patchouli, Frankincense, Corn, Coffee, Tubers, Vegetables, Bananas, Jackfruit, Potatoes. If viewed in terms of Geographics, fruit plants such as Dutch Eggplant, Passion Fruit, Pineapple, Watermelon, Apples, Oranges, Stroberry are also developed in this area. Durian is also very suitable to be developed in this area, the taste and aroma of durian originating from this area has a characteristic compared to durian originating from other regions. Unfortunately, durian is not found all the time because the traditional cultivation of durian cannot be found throughout the year, the harvesting period is still seasonal. Durian season is usually around December to January.

\section{Dairi Tourism Potential}

- Taman Iman Wisata Sitinjo

- Panorama of Lake Toba Beach

- Panorama of Sidiangkat Peak

- Lae Pondom Tourism Forest

- Silalahi Beach Tourism: Rumah Tanggal, Tumaras, Sialaman

- Pakpak Traditional House

- Panorama of Lae Nauli

- Lae Basbas Waterfall

- Lake above Mount Kempawa

- Panorama Letter "S"

- Deep Cave Panorama / Long Kendet Liang

- Lae Pendaroh Waterfall

- Historical objects of the Aceh Stone

- Jerro Pakpak building

- Kangkung Panorama

- Uruk Sembelin

- Lae Bonian's eyes
- Silemboyah Panorama

- Kerbo stone

\section{Inventory of Dairi District Traditional Food}

\section{A. Types of food}

1. Pelleng

The typical Dairi food that the Pakpak people believe is believed to have supernatural powers. This meal is usually served in the event of welcoming activities that are considered high risk, such as war and also in the event to reach the ideals or realize hope. for example the menanda ceremony, merkottas, meneppuh babah, or mbengket bages. The goal itself actually depends on the type of event or ceremony. If you want to open a field, usually this Pelleng presentation means to avoid danger. If you want to migrate to be monitored successfully. If you want to ask for a favor so that the proposal is accepted. When finished harvesting, pass the exam, get a job as a thanksgiving to the ruler and so on. There are two types of Pelleng for the Pakpak community, namely the Simsim, Classen and Boang pelleng and the Kepas and Pegagan typical pelleng. The function and meaning are the same, the only difference is the processing.

2. Nakan Merasa or Nakan Pagit

The ingredients are in the form of rice mixed with bungke (fruit from plants that taste bitter, inggir-inggir (Toba), singgaren (fragrant plants), rimbang, and eggplant. This mixture is then cooked with rice. known as perpre nakan feel or want to pagit (presenting bitter tastes), the treat is to feel or eat pagit means that pregnant women get the strength so that they avoid all kinds of illnesses, their thoughts: the mother's blood and the baby will feel bitter so the virus doesn't like it and bacteria, these foods are eaten during the womb aged 5 to 7 months, eating them in the morning when the sun is rising towards the zenith.

3. Nditak

Rice is finely ground and sifted, then mixed with brown sugar and coconut. Then head-clenched. Finished. That is what is called nditak. This dish is served during the ceremony of filing or flicking (tooth file) girls before adolescence (ampeampe flowers), also in the event of loading and giving peradupen namely the delivery of dowry before the wedding ceremony 
takes place. In this case the family of the bride is not provided. In guarding babah (completing satisfying mouth requests), the event which was held after other traditional events (marriage, harvest, annual ceremony) was also not a presentation. In addition to what has been mentioned, there are still a number of Pakpak typical foods or drinks served in traditional events.

4. Ginaru Ncor

Ginaru ncor is cooked rice into porridge and mixed with meal vinegar; Tangkasen pattern is acidified palm water (tuak), tenggi pattern which is fresh palm water or sap; tenggoli are sugar from palm, sugar cane, and honey bee.

5. Nakan Nggersing

Nakan nggersing is rice cooked with turmeric, and served by placing boiled chicken eggs on it.

\section{B. Processing methods}

1. Pelleng sir sir

Yellow Rice Seasoning:

1. 1 liter of white rice

2. Turmeric $300 \mathrm{gr}$

3. 300 grams of fruit acid

4. Chili 100 grams

5. Salt to taste

Procedure:

1. Puree ingredients 2 and 4

2. Squeeze the cored acid.

3. Cook rice as usual, after mixing with the mashed spices and give salt and acidic water.

Curry chicken seasoning:

1. 2 chickens ( 1 for pelleng sauce)

2. 200 grams of red chili

3. Coconut milk

4. 300 gr red onion

5. Garlic $150 \mathrm{gr}$

6. Turmeric $100 \mathrm{gr}$

7. Gongseng coconut $1 \frac{1 / 2}{2}$ coconut

8. Ginger $150 \mathrm{gr}$

9. Pecan $100 \mathrm{gr}$

10. Salt, pepper, coriander, bay leaf, serei. Sufficiently.

Procedure:

1. Puree ingredients 2, 4, 5, 6, 8, 9 .

2. Sauté until fragrant, add 10 spices and chicken that has been cut into pieces.

3. After half cooked, add coconut milk.

4. Wait until the coconut milk begins to recede. Then enter the ginger coconut.

5. Wait until the chicken is cooked

Pelleng sauce:
1. Cayenne pepper already colored $500 \mathrm{gr}$

2. Curly red pepper 200 grams 3 . Andaliman 200 gr

4. 100 grams of fruit acid

5 . Gongseng coconut $1 / 2$ coconut

6. Curry chicken that has been baked 1 tail

Procedure:

1. Puree cayenne pepper, red chili and andaliman.

2. Saute until you give a delicious aroma.

3. Add tangerine coconut, squeezed sour fruit and grilled chicken that has been unsweetened or cut into small pieces.

2. Feel

The ingredients are rice mixed with bungke (fruit from plants that taste bitter, inggir-inggir [Toba] singgaren (fragrant plants), rimbang, and eggplant. This mixture is then cooked with rice. This dish is especially for pregnant women in known events as perre feel that you will feel or want to sit (serving bitter tastes).

The treat is to feel or want to make it so that pregnant women get the strength so that they avoid all kinds of diseases. The way he thinks: the mother's blood and the baby will feel bitter so the virus and bacteria don't like it. This food is eaten at the age of 5 to 7 months. Eat it in the morning when the sun is rising towards the zenith.

3. Nditak Gabur

Material :

1. $2 \mathrm{~kg}$ rice flour

2. Grated coconut 1 coconut

3. 500 gr sugar

4. $1 \mathrm{~kg}$ of brown sugar

5. Salt to taste

Procedure:

1. Steam rice flour and coconut until cooked like sago.

2. After being cooked, mix sugar, shaved sugar, and salt.

3. After all the ingredients are mixed, then it can't be printed, with nitakdikepal with your hands until it's not really broken.

NB: Nditak can not be eaten directly or can be steamed again so that the texture is more supple and not easily dispersed when bitten.

\section{Ginaru Ncor}

Ginaru Ncor is a dish in the form of rice porridge cooked with Pak-pak's distinctive spices and various other spices. Making Ginaru Ncor is not like making ordinary rice porridge. Because before cooking rice must be ground first, so the porridge is very soft then the results. 
The mixture for rice that has been cooked into porridge is also a little unique, namely sweet potatoes and spices that have been mashed. For spices such as lemongrass, bay leaves and cikala acid do not need to be smoothed. Simply mashed and then sauteed, this is done so that the spices do not dissolve in the spices, because the spices are only as a complement.

This Ginaru Ncor is a food that is required with fiber. Because the mixture of various food ingredients is very numerous and complete. "Not only fiber requirements, but these foods are also very tasty. Ginaru Ncor is also food to increase appetite.

\section{Nakan Nggersing}

It is a special food for the Pakpak tribe, whose ingredients consist of mening rice (cut rice / menir), vegetables, among others; pumpkin leaves (bulung roroh), pariah leaves, spinach, leuh, sweet potato leaves (gadong jolor), young long bean leaves, pumpkin flowers, small pumpkin fruit, smells, kumange, garang-garang and tomato kampung (randat ) Sometimes added with wood fruit called ntarsa, it is also mixed with chicken sliced in small pieces and petai. Usually rice is cooked with turmeric, and the side dish is boiled eggs. The lajim is used in traditional ceremonies that are related to agriculture or choose (reject the reinforcements).

\section{Economic Aspects}

When viewed from an economic standpoint and the price of raw materials, traditional Dairi foods are still relatively expensive and of course this also makes it difficult for these foods to be sold in many places. Besides this, various regional cuisines are usually only made when there are special events related to traditional events and other family events.

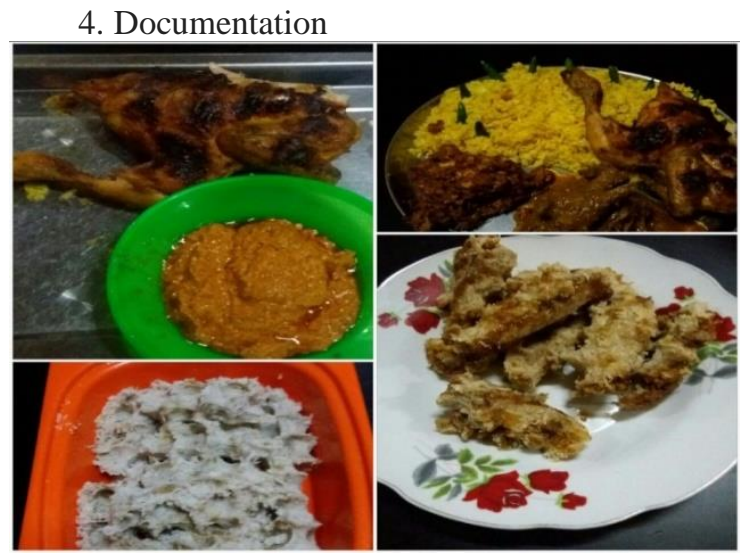

Figure 3. Various Traditional Dairi Foods

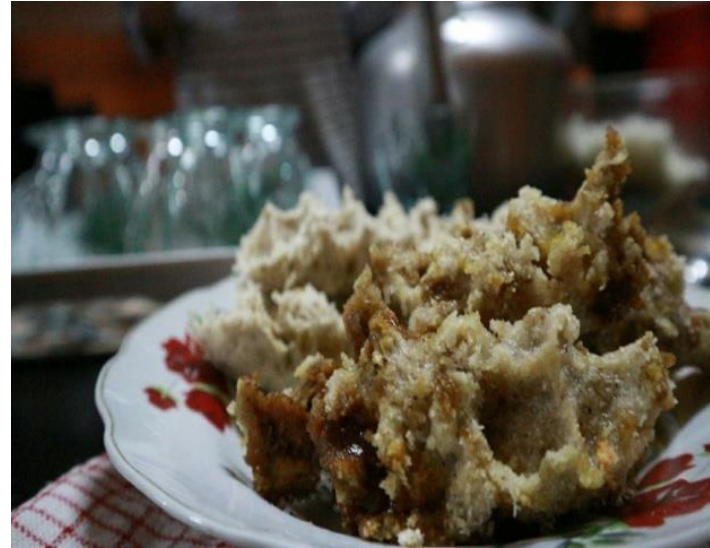

Figure 4. Nditak

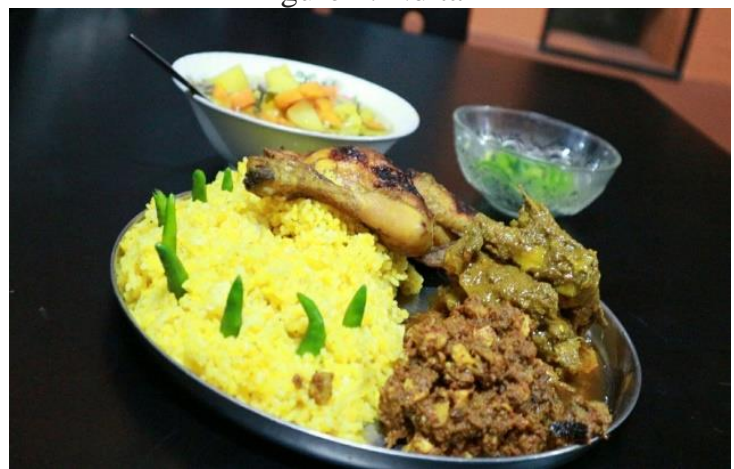

Figure 5. Pelleng

Traditional Food Development Strategies in Dairi Regency

Maintaining and improving the quality of Dairi traditional food products This strategy can be implemented through programs including:

1. Use of quality materials.

The quality of the material used is very influential on the food products produced. To produce good quality and good quality food products, the ingredients must be of good quality.

2. Utilization and use of modern technology in the selection of cooking tools and the selection of appropriate and correct cooking methods.

The quality of the food produced is not only from the raw materials used, but the use of tools and the selection of the right cooking method greatly affect the final results of the food made. With the development of technology in food processing we can choose one of these technologies so that they can still produce quality food. If the tools used to make these foods are right and functioning properly, and the processing methods used in accordance with the characteristics of food, will produce products. good quality food too. 
Development strategies that can be done include:

1. Increasing the diversity of Dairi traditional foods in menus served by restaurants in Dairi. This strategy can be implemented through programs including:

a) Lifting and introducing existing types of traditional Dairi food. The potential of various types of traditional Dairi foods in each sub-district in Dairi can be extracted and collected to be selected according to international gastronomy.

b) Modifying existing products by improving appearance, perfecting traditional Dairi food products or creating new Dairi food menus by not eliminating the traditional spice of Dairi food itself.

2. Carry out quality control of Dairi traditional food products. This strategy can be implemented in a way that includes:

a) Use of Standard Purchase Specification. To produce quality food, the raw materials and ingredients used must also be of quality)

b) Use of standard recipe (Recipe) Recipe plays a very important role for a cook. The existence of a standard recipe will help produce food of the same quality.

3. Improving and maintaining the consistency of the taste of traditional food can be done through programs such as:

a) Making standards of Dairi Rasa traditional food recipes that are inconsistent are mainly due to the absence of a standard in making traditional Dairi foods so that there are differences in the use of ingredients and processing methods from each person who makes.

Based on the results of interviews with related parties in Dairi, it is better if traditional food development strategies can be carried out by including:

1. Identification and re-inventory in detail of traditional foods in Dairi.

2. Developing profiles of traditional food in the region as food information and counseling materials.

3. Making attractive packaging that can last longer so that traditional food can be made by visitors who come to Dairi tourism objects especially for traditional Nditak foods.

4. Promoting.

5. Encourage the development of traditional food centers with relevant agencies, the private sector and the community.

6. Provision of soft credit for additional working capital.

\section{Promotion conducted by the Dairi Regency Government}

The local government of Dairi Regency has not focused the culinary area to become one of the attractions of tourists who come to visit Dairi, so that regional cuisine is only served when there are family events and local traditional pickles. Branding by so far only from agricultural products such as Coffee and Orange, has not yet entered into finished processed materials, so that in the future there will be a development of Dairi's agricultural products that are already well-known to be Branding designs of Dairi special foods and in combination with traditional cuisine which has been around for a long time, it is packaged into a product that is more attractive and economical.

This temporary promotion is only on presenting traditional Dairi dishes at every official government event, both in the level II and provincial levels.

We recommend that the promotion of traditional Dairi foods can be done through:

1. Advertising

The advertising function is to provide information to the market about the products sold and to influence consumers to be interested. Ads can be placed on mass media such as television, newspapers, magazines, or through the internet by utilizing digital technology cooperation through the website

2. Personal selling

In personal selling, there is a direct interaction between face-to-face contact between community seller purchases that are carried out by both parties, are individual and two-way so that the seller can immediately get a response as feedback about the wishes and preferences of the buyer, the delivery of news or conversation is very flexible because it can adjust to the conditions there is.

Meanwhile, from the distribution of questionnaires to resource persons and several community leaders related to Dairi's traditional culinary development, it can be concluded that:

1. Does this traditional Dairi food can be developed and sold in restaurants in general:

Answer: Dairi traditional food for now is not available in restaurants in Dairi and is difficult to develop because various types of dairi food in the inventory list are foods that are served for special customs and religious events.

2. Is the cost for making traditional food generally cheap?

Answer: The material used for making Dairi food is classified as a standard, relatively expensive 
ingredient, for example Kampung Chicken which is used to make Pelleng Pak Pak.

3. Do you think that this traditional Dairi food can be received by people from other regions

Answer: in general, the taste of Dairi cuisine is a pedass and a sword from Andaliman, indeed not all people can enjoy it comfortably, but it is precisely this unique taste that will make Dairi cuisine have its own place in the tongue of the culinary lover.

4. How long has the support of the local government been related to the development of traditional food ......

Answer: The local government strongly supports Dairi's culinary development, as evidenced on every occasion there is an official event in the government, so to represent Dairi, some types of food are always served, but for the development of entrepreneurship that has not been realized until now.

From the above questions can be analyzed that traditional Dairi dishes are still difficult to develop and sell into a restaurant menu because usually these traditional foods are made for special events related to traditional activities. In addition, the ingredients used tend to be more expensive and spicy and spicy because they use specific ingredients such as andaliman.

Whereas for the Dairi Regency government support related to the development of traditional cuisine to date it is quite good where in every provincial level government event Dairi traditional cuisine is always served in banquets so that people can get to know Dairi cuisine both in taste and philosophy.

It is expected that in the future the commitment of the existing local government can be further developed so that traditional Dairi cuisine that is now commonly used by the community can be packaged well and made a culinary icon of Dairi Regency.

\section{CONCLUSIONS AND RECOMMENDATIONS}

\section{Conclusion}

1. An inventory of traditional Dairi food has been carried out in writing by the local government and this data is used as the culinary data of Dairi district so far, the current Dairi Traditional Food is Pelleng, Nakan Merasa or Nakan Pagit, Nditak, Ginaru Ncor and Nakan Nggersing.

2. The Development Strategy that is needed is the identification and re-inventory of traditional food, compiling profiles of traditional food in the region as food information and counseling materials, promotion, encouraging the development of traditional food centers with related agencies, the private sector and the public as well as providing soft loans for additional capital.

3. Promotion is only limited to official government activities, both at level II and provincial level. The Dairi government has not specifically done the traditional Dairi food promotion, people who come to visit Dairi tend to only buy agricultural products such as Sidikalang Coffee and Dairi Orange. As for the type of food that has not been packaged properly.

\section{Suggestion}

1. We recommend that from the inventory of traditional food that already exists today can be made into data and developed into one of the culinary icons of Dairi Regency.

2. Development strategies that have been identified according to the needs of the resource persons should be realized in order to improve the economy of the community.

3. The Dairi Regency Government should start promoting the culinary richness of Dairi Regency so that there are alternatives to the mainstay products besides the results of agricultural products that have been available and are expected to become Branding for Dairi's special food.

\section{REFERENCES}

Jessica Kwik. 2008. Traditional Food Knowledge: A Case Study of an Immigrant Canadian "Foodscape" Environments: a journal of interdisciplinary studies/revue d'études interdisciplinaires

Rahman, Fadly. 2016. Jejak Rasa Nusantara: Sejarah Makanan Indonesia, Jakarta: Gramedia Pustaka Utama

Rosyidi, Djalal. 2011. Macam-Macam Makanan Tradisional yang Terbuat dari Hasil Ternak yang Beredar di Kota Malang. Jurnal Ilmu dan Teknologi Hasil Ternak, Agustus 2006, Hal 24-34 Vol. 1, No. ISSN : 1978 - 0303.

Sukardi. 2011. Metodologi Penelitian Pendidikan. Yogyakarta: Bumi Aksara.

http://www.suaramerdeka.com/v1/index.php/read/news/2017/03/ 07/148082/Gerakan-Makanan-Tradisional-HarusDigalakkan

http://www.deptan.go.id/pesantren/bkp/PKP/organisasi.htm Jessica Kwik. 2017.

http://id.wikipedia.org/wiki/Makanan Tradisional Dairi, diakses tgl 10 Juli 2017 Pukul 15.00 wib.

http://id.wikipedia.org/wiki/Sumatera Utara, diakses tgl $10 \mathrm{Juli}$ 2017 Pukul 17.00 wib.

www.Dairi.go.id 